\title{
Anti-double Stranded DNA Antibodies: Origin, Pathogenicity, and Targeted Therapies
}

\author{
Xiaoyu Wang and Yumin Xia* \\ Department of Dermatology, The Second Affiliated Hospital, School of Medicine, Xi'an Jiaotong University, Xi'an, China
}

Systemic lupus erythematosus (SLE) is characterized by high-titer serological autoantibodies, including antibodies that bind to double-stranded DNA (dsDNA). The origin, specificity, and pathogenicity of anti-dsDNA antibodies have been studied from a wider perspective. These autoantibodies have been suggested to contribute to multiple end-organ injuries, especially to lupus nephritis, in patients with SLE. Moreover, serum levels of anti-DNA antibodies fluctuate with disease activity in patients with SLE. By directly binding to self-antigens or indirectly forming immune complexes, anti-dsDNA antibodies can accumulate in the glomerular and tubular basement membrane. These autoantibodies can also trigger the complement cascade, penetrate into living cells, modulate gene expression, and even induce profibrotic phenotypes of renal cells. In

Edited by:

Marie-Agnes Dragon-Durey, Université Paris Descartes, France

Reviewed by:

Umesh S. Deshmukh, Oklahoma Medical Research Foundation, United States Batteux Frederic

Université Paris Descartes, France

*Correspondence:

Yumin Xia xiayumin1202@163.com; yuminxia@mail.xjtu.edu.cn

Specialty section:

This article was submitted to Autoimmune and Autoinflammatory

Disorders,

a section of the journal

Frontiers in Immunology

Received: 02 November 2018 Accepted: 03 July 2019

Published: 17 July 2019

Citation:

Wang X and Xia Y (2019) Anti-double Stranded DNA Antibodies: Origin,

Pathogenicity, and Targeted

Therapies. Front. Immunol. 10:1667. doi: 10.3389/fimmu.2019.01667 addition, the expression of suppressor of cytokine signaling 1 is reduced by anti-DNA antibodies simultaneously with upregulation of profibrotic genes. Anti-dsDNA antibodies may even participate in the pathogenesis of SLE by catalyzing hydrolysis of certain DNA molecules or peptides in cells. Recently, anti-dsDNA antibodies have been explored in greater depth as a therapeutic target in the management of SLE. A substantial amount of data indicates that blockade of pathogenic anti-dsDNA antibodies can prevent or even reverse organ damage in murine models of SLE. This review focuses on the recent research advances regarding the origin, specificity, classification, and pathogenicity of anti-dsDNA antibodies and highlights the emerging therapies associated with them.

Keywords: anti-dsDNA antibody, catalysis, lupus nephritis, peptide, suppressor of cytokine signaling 1 (SOCS1), systemic lupus erythematosus (SLE)

\section{INTRODUCTION}

Systemic lupus erythematosus (SLE) is a severe disease that involves dysregulation of the immune system, excessive production of pathogenic autoantibodies (and their upregulation in serum), and multiple immune-system-mediated injuries. Anti-double-stranded (ds)DNA antibodies have been some of the classic diagnostic and nosological criteria of SLE since 1982. In 2012, the high titer of anti-dsDNA antibodies in serum accompanied by biopsy-proven lupus nephritis (LN) was accepted as an independent classification criterion for SLE by the Systemic Lupus International Collaborating Clinics (1). However, the wide spectrum of molecular antibody specificity and complex contexts of antibody generation, as well as the diverse antigen structures to which these antibodies bind, make anti-dsDNA antibodies difficult to accept without further distinction as a classification criterion for SLE (1). Pathogenic anti-dsDNA autoantibodies react with DNA but are 
not strictly specific to it. Multiple self-antigens can be recognized by anti-dsDNA antibodies, subsequently triggering apoptosis, inflammatory responses, and tissue fibrosis. Recently, synthesized peptides that mimic a molecular DNA structure were reported to specifically recognize and interact with the anti-dsDNA antibodies, thus pointing to a novel therapeutic opportunity via inhibition of the antigen recognition of anti-dsDNA antibodies $(2,3)$. This review sheds light on the involvement of anti-dsDNA antibodies in the progression of SLE and provides new insights into the therapies for SLE.

\section{THE ORIGIN OF ANTI-DSDNA ANTIBODIES}

Normally, nuclear antigens, such as dsDNA, are not accessible to the immune system because they are restricted to the nucleus and mitochondria and are quickly degraded by DNases in the cytoplasm and endosomes. However, nuclear materials can be released from apoptotic cells after exposure to ultraviolet light, infection, and drugs. Cells undergo death via different processes. During NETosis, cells extrude DNA and neutrophil extracellular traps (NETs), in which DNA is covered by anti-bacterial substances $(4,5)$. In apoptosis, DNA cleavage leads to the formation of apoptotic bodies, which contain DNA-bound microparticles (6). In necrosis, high-molecular-weight DNA is liberated after cell lysis.

The released DNA can be recognized by anti-DNA antibodies and compose immune complexes. Extracellular nucleic acids containing immune complexes can be captured by immature dendritic cells (iDCs) via Fc $\gamma$ Rs; these cells subsequently get activated and migrate from peripheral tissues to lymphatic organs, where iDCs undergo maturation (7). Activated DCs induce the over-representation of costimulatory molecules, such as CD80, CD86, and PD-L1 $(8,9)$. Furthermore, these DCs trigger redistribution of the MHC II molecule and production of proinflammatory cytokines, such as interferon $\alpha$ (IFN- $\alpha)$, tumor necrosis factor (TNF)- $\alpha$, and interleukin 6 (IL-6), which are interrelated with the activation of $\mathrm{B}$ cells and $\mathrm{T}$ cells $(10,11)$. The immune complexes act as an antigen to stimulate B cells by activating the recognition receptors, such as Toll-like receptors (TLRs). TLR7 and TLR9 are the key receptors for the recognition of self-DNA or immune complexes and trigger the production of IFN-1 and inflammatory responses $(12,13)$. There are also some intracellular sensors in B cells and in other immune cells that can identify foreign DNA or self-DNA, including TLR9 and cyclic guanosine monophosphate-adenosine monophosphate, contributing to the overproduction of IFN-1 (14-16). Multiple signaling pathways are involved in the IFN-1 production process, which are activated after the interaction between sensors and DNA or another nucleic acid, such as pathways dependent on TLR9 and on stimulator of interferon genes $(16,17)$. As a key factor in the regulation of the innate immune response, IFN-1 can upregulate B cell-activating factor, promote B-cell differentiation, and suppress regulatory $\mathrm{T}$ cell (Treg) function $(18,19)$. With the help of IFN-1, autoreactive B cells undergo amplification, somatic mutation of immunoglobulin variable region genes, and class switch recombination, resulting in highaffinity immunoglobulin $\mathrm{G}$ (IgG) (20). In addition to suppressing Treg cells, IFN-1 can promote Th17 differentiation and increase the number of activated $\mathrm{T}$ cells (21). The insufficiency of Treg function contributes to the loss of immune tolerance in SLE via the TLR pathway (22). TLR9 can recognize dsDNA with a CpG motif and is dynamically upregulated in B cells (23). After a knockdown of TLR9, B cells produce fewer anti-dsDNA antibodies, and SLE syndrome is ameliorated in mice (24).

Moreover, autophagy is associated with the immune regulation and is essential for the homeostasis in immune cells. LC3-associated phagocytosis is an autophagy pathway that participates in the endocytosis of DNA or immune complexes by immune cells, especially plasmacytoid DCs. LC3 induces production of IFN- $\alpha$ via the TLR9 pathway in plasmacytoid DCs, whereas beclin-1, another member of the autophagy pathway, inhibits the production of IFN- $\alpha$ (25, 26). Beclin-1 knockdown macrophages can remarkably reduce antibody production and deposition of renal immune complexes, suggesting that autophagy may be an additional mechanism for the production of these antibodies (27).

Anti-dsDNA antibodies recognize diverse DNA structures, including single-stranded (ss)DNA, Z-DNA, bent or elongated dsDNA, DNA:RNA hybrids, locked-nucleic acids, and peptide: nucleic acid hybrids (28). Anti-dsDNA antibodies can bind to a complex of native dsDNA or modified DNA that contains a thymine dimer (generated during DNA photodamage). The chemically modified dsDNA may acquire a higher affinity for autoantibodies and form more stable complexes (29). Otherwise, antibodies can react with many non-DNA antigens in target cells and tissues: annexin II, $\alpha$-actinin, laminin, collagen III, collagen IV, entactin, complement receptor type 1 (C1q), Nmethyl-d-aspartate receptor (NMDAR), ribosomal $\mathrm{P}$ proteins, heparan sulfate, and others (30-39) (Table 1). Although there are no obvious similarities between DNA and potential crossreactive antigens, some peptides can bind to both murine and human anti-dsDNA antibodies by mimicking a molecular DNA structure $(2,3)$.

Anti-dsDNA antibodies have different subclasses, including IgA, IgE, IgG, and IgM. Nonetheless, not all of them contribute equally to tissue injuries in SLE. It is IgG and IgA but not IgM that correlate with disease activity in humans. Most pathogenic antibodies are affiliated with the IgG class in SLE patients (47). IgM antibodies seem to be protective by enhancing the elimination of apoptotic material and via immunomodulatory effects, thereby alleviating renal dysfunction (48). The class switch and somatic mutations of the IgG variable chain can increase the risk of pathological changes. Activation-induced deaminase (AID) in B cells is a key enzyme required for such processes, as confirmed in transgenic or non-transgenic murine models, where a loss of tolerance is accompanied by high production of class-switched IgG (49-51). When lacking AID, lupus-prone mice produce more anti-dsDNA IgM, but not the high-affinity IgG, and show substantial attenuation 
TABLE 1 | Antigenic recognition of anti-dsDNA antibodies.

\begin{tabular}{|c|c|c|c|}
\hline $\begin{array}{l}\text { Self- } \\
\text { antigen }\end{array}$ & Cells/Tissue & $\begin{array}{l}\text { Contribution } \\
\text { to SLE }\end{array}$ & References \\
\hline Annexin II & $\begin{array}{l}\text { - Mesangial } \\
\text { cells } \\
\text { - Epithelial cells }\end{array}$ & $\begin{array}{l}\text { - Activate p38 MAPK, JNK, } \\
\text { and AKT } \\
\text { - Induce secretion of IL-6 }\end{array}$ & $(30)$ \\
\hline $\begin{array}{l}\text { Alpha- } \\
\text { actinin }\end{array}$ & $\begin{array}{l}\text { - Mesangial } \\
\text { cells }\end{array}$ & $\begin{array}{l}\text { - Change cell shape and } \\
\text { migration } \\
\text { - Increase production of } \\
\text { anti-chromatin antibody } \\
\text { - Induce glomerular } \\
\text { IgG deposition }\end{array}$ & (38) \\
\hline Laminin & $\begin{array}{l}\text { - Glomerular } \\
\text { matrix }\end{array}$ & $\begin{array}{l}\text { - } \text { - } \text { Drigger inflammation } \\
\text { ECM the structure of } \\
\text { - Inhibit formation of the } \\
\text { capillary structure }\end{array}$ & $(40)$ \\
\hline $\begin{array}{l}\text { Collagen } \\
\text { III/ IV }\end{array}$ & $\begin{array}{l}\text { - Glomerular } \\
\text { basement } \\
\text { membrane } \\
\text { - Glomerular } \\
\text { matrix } \\
\text { - Keratinocytes }\end{array}$ & $\begin{array}{l}\text { - Exacerbate inflammatory } \\
\text { infiltration } \\
\text { - Activate the Fn14 and } \\
\text { socS1 pathways }\end{array}$ & $(33,41,42)$ \\
\hline C1q & - Sera & $\begin{array}{l}\text { - Induce immune complex } \\
\text { deposition } \\
\text { - Activate FcR-bearing cells } \\
\text { - Induce production of } \\
\text { anti-C1q antibodies }\end{array}$ & (36) \\
\hline NMDAR & $\begin{array}{l}\text { - Neuronal } \\
\text { cells }\end{array}$ & $\begin{array}{l}\text { - Apoptosis of neuronal cells } \\
\text { - Enhance expression of } \\
\text { proinflammatory factor } \\
\text { - Damage } \\
\text { blood-brain barrier }\end{array}$ & $(43-45)$ \\
\hline Entactin & $\begin{array}{l}\text { - Glomerular } \\
\text { basement } \\
\text { membrane }\end{array}$ & $\begin{array}{l}\text { - Increase production of } \\
\text { anti-entactin antibodies } \\
\text { - Promote the damage to } \\
\text { glomerular basement } \\
\text { membrane structure }\end{array}$ & (39) \\
\hline Ribosomal P & $\begin{array}{l}\text { - Hepatocytes } \\
\text { - Lymphocytes } \\
\text { - Mesangial cells }\end{array}$ & $\begin{array}{l}\text { - Induce production of } \\
\text { anti-Rib-P antibody } \\
\text { - Enhance secretion of } \\
\text { IFN- } \alpha \text { and IL-10 } \\
\text { - Induce T helper } 1 \\
\text { responses }\end{array}$ & (37) \\
\hline $\begin{array}{l}\text { Heparan } \\
\text { sulfate }\end{array}$ & $\begin{array}{l}\text { - Glomerular } \\
\text { basement } \\
\text { membrane } \\
\text { - Mesangial } \\
\text { matrix }\end{array}$ & $\begin{array}{l}\text { - Mediate penetration of } \\
\text { living cells } \\
\text { - Induce cell apoptosis } \\
\text { and inflammation }\end{array}$ & $(35,46)$ \\
\hline
\end{tabular}

of glomerulonephritis and longer survival than do the wildtype mice (52). In SLE, DNA emerges as an inducer of an antigen-driven selection of B cells and is essential for a somatic mutation. During this process, the insertion of positively charged amino acids (for example, asparagine, arginine, and lysine residues) into complementarity-determining regions (CDRs) is critical for the binding of high-affinity dsDNA to the negatively charged phosphodiester backbone $(53,54)$. Among almost all IgG antibodies, anti-DNA IgG may have the potential for recognizing somatically produced idiotypes (53). Besides, the IgA and IgE subclasses of anti-DNA antibodies are implicated, independently or in combination with IgG, in lupus nephritis (LN) $(47,55,56)$.

\section{THE DETECTION OF ANTI-DSDNA ANTIBODIES}

Tests for anti-DNA antibodies can be positive at least 2 years before clinical diagnosis of SLE, and a surge in serum levels can present as a predictor for a severe SLE flare-up in the following 6 months (57). Subsequently, patients may undergo a course of relapsing-remitting with differences in the possibility of a flare between individuals. Anti-dsDNA antibodies emerge as a heterogeneous population in SLE, whereas they can be detected in some non-SLE patients with rheumatic symptoms, indicating that the employment of anti-dsDNA antibodies as a criterion for diagnosis and classification without subdivision may result in misdiagnosis and misclassifying of $\operatorname{SLE}(58,59)$.

There are a variety of tests for anti-dsDNA antibody detection, such as the Farr radioimmunoassay (FARR-RIA), Crithidia luciliae indirect immunofluorescence test (CLIFT), and enzymelinked immunosorbent assays (ELISA) (Table 2). The former two assays have been well-demonstrated for diagnosis and prognosis, whereas ELISAs are more valuable for detecting high-avidity anti-dsDNA antibodies in clinical laboratories and most closely associated with SLE activity (60). However, the materials used in assays limit their utilization, and researchers have been working on developing new suitable assays with high sensitivity and specificity. Panza et al. explored a novel assay that uses complexed histone peptides (PK201/CAT plasmid) with a fragment from Crithidia luciliae, which has more simple procedures (61). We utilized trypoanosoma equiperdum (TE) that containing uniformed dsDNA but no histone in the cell nucleus or kinetonucleus, which is much easier for purification with a simpler structure (62). Poulsen et al. developed a flowinduced dispersion analysis, offering a more sequence-specific antibody characterization via utilizing short and well-defined dsDNA sequences (63). It also exhibits the advantages of shorter analysis time and less sample volume consumption. Although the association between high levels of anti-DNA antibodies and disease activity has been widely appreciated, no signal-detecting approach can reliably evaluate disease activity in SLE. The current assays are not sufficient for detecting all of the antibodies in sera, especially the low-level antibodies, or the immune complex. Thus, at least two assays should be used for better evaluation and higher accuracy.

\section{THE PATHOGENICITY OF ANTI-DSDNA ANTIBODIES}

\section{Anti-dsDNA IgG Correlates Closely With LN}

Among the affected organs, renal involvement indicates major internal damage in SLE patients. Anti-dsDNA antibodies are present in serum in nearly $80 \%$ of patients with LN. AntidsDNA antibodies directly or indirectly interact with renal antigens, thus producing immune complexes (32) Nevertheless, renal damage is not initiated solely by the complexes of 
TABLE 2 | Detection methods with strengths and weaknesses.

\begin{tabular}{|c|c|c|}
\hline Methods & Strengths & Weaknesses \\
\hline FARR-RIA & $\begin{array}{l}\text { - Detect high-avidity } \\
\text { antibodies } \\
\text { - High specificity } \\
\text { - Qualitative assay }\end{array}$ & $\begin{array}{l}\text { - Low sensitivity } \\
\text { - Use radioactive material }\end{array}$ \\
\hline CLIFT & $\begin{array}{l}\text { - Detect high-avidity } \\
\text { antibodies } \\
\text { - Qualitative assay } \\
\text { - High sensitivity } \\
\text { - High specificity }\end{array}$ & $\begin{array}{l}\text { - Only score the kinetoplast } \\
\text { fluorescence since nuclei } \\
\text { always contain many antigens } \\
\text { other than DNA } \\
\text { - Lack of accurate serum titer }\end{array}$ \\
\hline ELISA & $\begin{array}{l}\text { - Detect low and high } \\
\text { avidity antibodies } \\
\text { - Quantitative assays } \\
\text { - High sensitivity }\end{array}$ & $\begin{array}{l}\text { - Low specificity } \\
\text { - False-positive results due to } \\
\text { binding of immune complexes } \\
\text { (with negatively } \\
\text { charged moieties) }\end{array}$ \\
\hline
\end{tabular}

a chromatin fragment and IgG depositing in the mesangial matrix or glomerular basement membranes. In some studies, enrichment of anti-dsDNA antibodies was not present in all extracted samples from the patients with proliferative LN and accounted for $<10 \%$ of all antibodies, where overexpression of antibodies to $\mathrm{C1q}, \mathrm{Sm}, \mathrm{SSA}$, and SSB was also responsible for the process (64). Similarly, researchers also discovered that a mouse strain (NZM.C57Lc4) with genetic modification has a severe renal disorder and the serological testing for antidsDNA antibodies yielded negative results (65). Moreover, antidsDNA IgG does not exert nephritogenic effects without the exposure of chromatin fragments in glomerular membranes and matrices (66). These results confirm that the initiation of $\mathrm{LN}$ is promoted by multiple autoantibodies, not by their single type. Reasonable factors that can explain this discrepancy including the subtypes of antibodies with differences in reactive specificity and affinity that have been described previously, differences in mouse strains utilized for the creation of animal models and other factors need to be illustrated in the future. Despite the doubts about their nephritogenic role in launching LN, the pivotal role of anti-dsDNA IgG and immune complexes in the acceleration of the LN process has been underscored by a wealth of evidence, where their effects on renal resident cells are well-documented (Table 3).

Most immunoglobulins are unable to penetrate into living cells (67). However, anti-dsDNA antibodies can penetrate into cells and engage in an interplay with targets. Glomerular cells, hepatocytes, monocytes, fibroblasts, and neuronal cells are vulnerable to penetration by anti-DNA antibodies, mirroring the findings in the liver, spleen, and skin after treatment with penetrating antibodies in vivo $(68,69)$. The cellular penetration of antibodies is assisted by $\mathrm{F}(\mathrm{ab})^{\prime} 2$ fragments with the mediation of the antigen-antibody binding region, which is also temperature-dependent and energy-consuming (70). Although the Fc fragment of an anti-DNA antibody contributes to its binding activity with monogamous bivalency, in which both Fab combining sites come into contact with DNA, the binding is not inhibited by the blockage of Fc receptor in mesangial cells $(71,72)$. In addition, the existence of manifold charged
TABLE 3 | Effects on renal cell types.

\begin{tabular}{|c|c|c|c|}
\hline Cell type & Proliferation & Inflammation & Fibrogenesis \\
\hline Mesangial cells & Increase/Decrease? • & 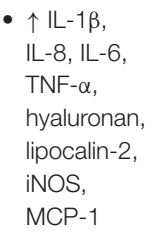 & $\begin{array}{l}\text { - } \uparrow \quad \text { PKC, TGF- } \\
\beta 1 / M A P K, \\
\text { JAK2/STAT1 } \\
\text { - } \uparrow \quad \text { TGF- } \beta 1, \quad \text { F-actin } \\
\text { - } \downarrow \text { SOCS1 }\end{array}$ \\
\hline PTECs & - & $\begin{array}{l}\text { - IL-6, IL-8, } \\
\text { TNF- } \alpha, \\
\text { MCP-1, } \\
\text { (NF)-кB, } \\
\text { IP-10, } \\
\text { MIP-1a, } \\
\text { ICAM-1, } \\
\text { VCAM-1 }\end{array}$ & $\begin{array}{l}\text { - } \uparrow \text { TWEAK/Fn14 } \\
\text { - } \uparrow \quad \text { MAPK, EMT, } \\
\text { C-JNK, ERK, p38, } \\
\text { Akt, JAK2/STAT1 } \\
\text { - } \downarrow \text { SOCS1 }\end{array}$ \\
\hline Endothelial cells & Increase/Decrease? • & $\begin{array}{l}\text { - } \uparrow \text { IL-1 } 1 \beta \\
\text { IL-8, IL-6, } \\
\text { TNF- } \alpha\end{array}$ & $\begin{aligned}- & \uparrow \text { JAK2/STAT1 } \\
& \downarrow \text { SOCS1 }\end{aligned}$ \\
\hline
\end{tabular}

amino acids in CDRs is a specific feature of penetrating antibodies, which is explained by the energy-independent electrostatic interactions of arginine residues in the CDR2 and CDR3 with the negatively charged sulfated polysaccharides on the cell surface $(68,73)$, suggesting that cell penetration is an intrinsic property of anti-dsDNA antibodies. The DNAhistone complexes binding to purified cell-penetrating antibodies extracellularly can significantly enhance their subsequent cell entry depending on the environment (70). Besides, a wide variety of cognate nuclear antigens can function as endocytic receptors and promote subsequent internalization of antibodies into the cell, e.g., ribosomal P proteins (37), C1q (36), annexin II (30), $\alpha$-actinin (38), and heparan sulfate (35, 46), further confirmed that the antigen-antibody mediation is crucial for the penetration mechanism. Although it is still unclear how anti-dsDNA antibodies actually cross the cell membrane, these data provide novel insights into antibodybinding endocytic receptors and elucidate their pathogenic role in SLE.

The penetrating anti-DNA antibodies can affect the proliferation and apoptosis of resident cells in LN, but the exact effect remains controversial. The anti-DNA IgG purified from the serum of LN patients has been shown to downregulate miR-10a and to trigger the proliferation of mesangial cells by targeting HOXA1, KLF4, and CREB1. Concomitantly, the expression of IL-6 is also enhanced, which is a crucial cytokine for promotion of the processes of cell proliferation and inflammation (74). Similar effects on cell proliferation are also seen in proximal renal tubular epithelial cells (PTECs) after exposure to the human anti-DNA antibodies; this treatment is associated with upregulated secretion of TNF- $\alpha$, IL- $1 \beta$, and IL- 6 (75). These findings indicate that such antibodies can promote the proliferation of renal cells mainly by modulating the relevant inflammatory cytokines. These findings are also supported by the characteristic biopsy lesions of LN with deposition of immune complexes, hypercellularity of mesangial cells and epithelial cells, 
and infiltration by inflammatory cells. However, monoclonal and polyclonal anti-dsDNA antibodies show the ability to induce apoptosis, either by reacting with antigens on the cellular membrane or by entering the cell (76). Apoptosis can also be induced by these autoantibodies via upregulation of extracellular regulated kinase (ERK) activation and $\mathrm{Bcl}-2$ production in murine mesangial cells. Endoplasmic-reticulum stress is upregulated in human mesangial cells after stimulation by anti-dsDNA antibodies, with activation of nuclear factor-kappa $\mathrm{B}(\mathrm{NF}-\kappa \mathrm{B})$ and increased expression of relevant inflammatory cytokines (72). This phenomenon may account for the apoptosis of mesangial cells, because enhanced endoplasmic-reticulum stress can cause cell death by changing the expression of multiple factors, including $\mathrm{CHOP}$ and $\mathrm{Bcl}-2$, as discussed by Iurlaro (77). This discrepancy may be a result of the differences in the methods or circumstances of in vitro studies, but the diffuse proliferation can be observed in renal biopsy specimens from LN patients. Upregulation of apoptosis can manifest itself as DNA cleavage in inflammatory lesions as well as increased lysis of renal proximal tubular cells in the presence of complement (78). The apoptosis of podocytes leads to the destruction of glomerular basement membranes, and this event is accompanied by the aggravated progression of inflammation and fibrogenesis in renal tissues with the proliferation of mesangial cells and PTECs.

It is well-known that accumulation of inflammatory cytokines is sufficient for accelerating the recruitment of immune cells and the induction of inflammatory and fibrogenic processes promoting kidney damage. A wealth of proinflammatory factors, including monocyte chemotactic protein 1 (MCP-1), TNF$\alpha$, IL-1 $\beta$, IL-6, IL-8, hyaluronan, lipocalin-2, and inducible nitric oxide synthase, are overexpressed in both human and murine mesangial cells upon stimulation with anti-dsDNA antibodies $(72,79,80)$. Consistently with this evidence, the amounts of these cytokines have been shown to increase in human PTECs under the influence of anti-dsDNA antibodymediated activation of the mitogen-activated protein kinase (MAPK) pathway; these factors further trigger the infiltration of monocytes and macrophages (81). These cytokines not only augment the infiltration by inflammatory cells but also increase the synthesis of fibronectin, eventually reproducing the features of tubulointerstitial fibrosis (41). Anti-dsDNA antibodies also sustain endoplasmic-reticulum stress and activated NF$\kappa \mathrm{B}$ accompanied by overexpression of cytokines in mesangial cells, resulting in a chronic inflammatory response and renal tissue damage (72). The high-titer anti-dsDNA antibodies are always accompanied by overexpression of TLR9 in podocytes, leading to increased production of TNF- $\alpha$, IL-6, and IFN- $\gamma$ (82). Besides, a multitude of signaling pathways are activated or involved in the autoantibody-mediated proinflammatory response. Excessive or persistent activation of tumor necrosis factor-like weak inducer of apoptosis (TWEAK)/fibroblast growth factor-inducible 14 (Fn14) signaling cascade positively correlates with the progression of LN. Anti-DNA IgG enhances the expression of Fn14 in keratinocytes through recognizing and binding to self-antigen, such as collagen III, indicating a relation between anti-DNA antibodies and the TWEAK/Fn14 signals (33). The mRNA expression levels of TWEAK and
Fn14 increase in the glomeruli and tubulointerstitium in both LN patients and in a mouse model and act as an inducer of constitutive nuclear factor (NF-кB) activation, which mediates the expression of MCP-1, interferon $\gamma$-induced protein 10 (IP-10), macrophage inflammatory protein 1a, intercellular adhesion molecule 1 , and vascular cell adhesion molecule 1 (83, 84). Additionally, MAPK, epithelial-to-mesenchymal transition (EMT), c-Jun N-terminal kinase, ERK, p38, and serine/threonine kinase Akt are also involved in TWEAK/Fn14 activation and downstream inflammatory and fibrotic responses $(85,86)$. Although the precise mechanisms of interaction of anti-DNA IgG and TWEAK/Fn14 have not been directly confirmed, anti-TWEAK antibodies, as well as Fn14 deficiency, are known to ameliorate renal damage induced by anti-dsDNA IgG in a murine model. Inhibition of TWEAK/Fn14 decreases renal IgG deposition without influencing serum anti-DNA IgG levels by relieving inflammation and protecting the filtration barrier, further confirming the crucial participation of the TWEAK/Fn14 signaling pathway in anti-DNA IgG-mediated LN (87-89).

A persistent chronic inflammatory response is always followed by fibrogenesis when there is no effective intervention, thereby leading to abnormal structure and dysfunction of kidneys with characteristic oversecretion of profibrogenic chemokines. Fibronectin is critical for fibrotic progression in glomerulonephritis and is distributed widely in the mesangial matrix, glomerular, and tubular basement membranes, and Bowman's capsule. The formation of glomerular fibronectin is enhanced both in patients and mice with active LN $(90,91)$. We have demonstrated that anti-dsDNA IgG contributes to renal fibrosis by downregulating suppressor of cytokine signaling 1 (SOCS1) and activating Janus kinase/signal transducer and activator of transcription 1 signals, which modulate the expression of profibrotic genes, transforming growth factor beta 1 (TGF- $\beta 1$ ), platelet-derived growth factor B, and connective tissue growth factor $(92,93)$. In addition to SOCS1, protein kinase $\mathrm{C}$ signaling is also simulated by anti-dsDNA antibodies with increased secretion of TGF- $\beta 1$ (94). As a profibrotic growth factor, TGF- $\beta 1$ is responsible for the cellular myofibroblastlike phenotype switch, in which the assembly of the actin cytoskeleton induces the synthesis of plasminogen activator inhibitor 1 through the TGF- $\beta 1 /$ MAPK pathway in mesangial cells, with an accumulation of the extracellular matrix (9597). Moreover, pathogenic anti-dsDNA antibodies cross-react with alpha-actinin 4; these data account for the promotion of myofibroblast-like phenotypic changes via upregulation of fibrogenic factors in mesangial cells, including F-actin and TGF$\beta 1$, as confirmed both in vitro and in vivo $(38,98)$. AntiDNA antibodies can also enhance the phenotypic changes or EMT in cultured PTECs. The activation of EMT with increased mesenchymal markers contributes to the interstitial infiltration by leukocytes and to tubule-interstitial fibrosis (75). Therefore, we can conclude that anti-dsDNA antibodies play a crucial part in the inflammatory and fibrogenic mechanisms of LN (Figure 1); however, the complicated network of inflammatory cytokines and intricate signaling pathways should be investigated further. 


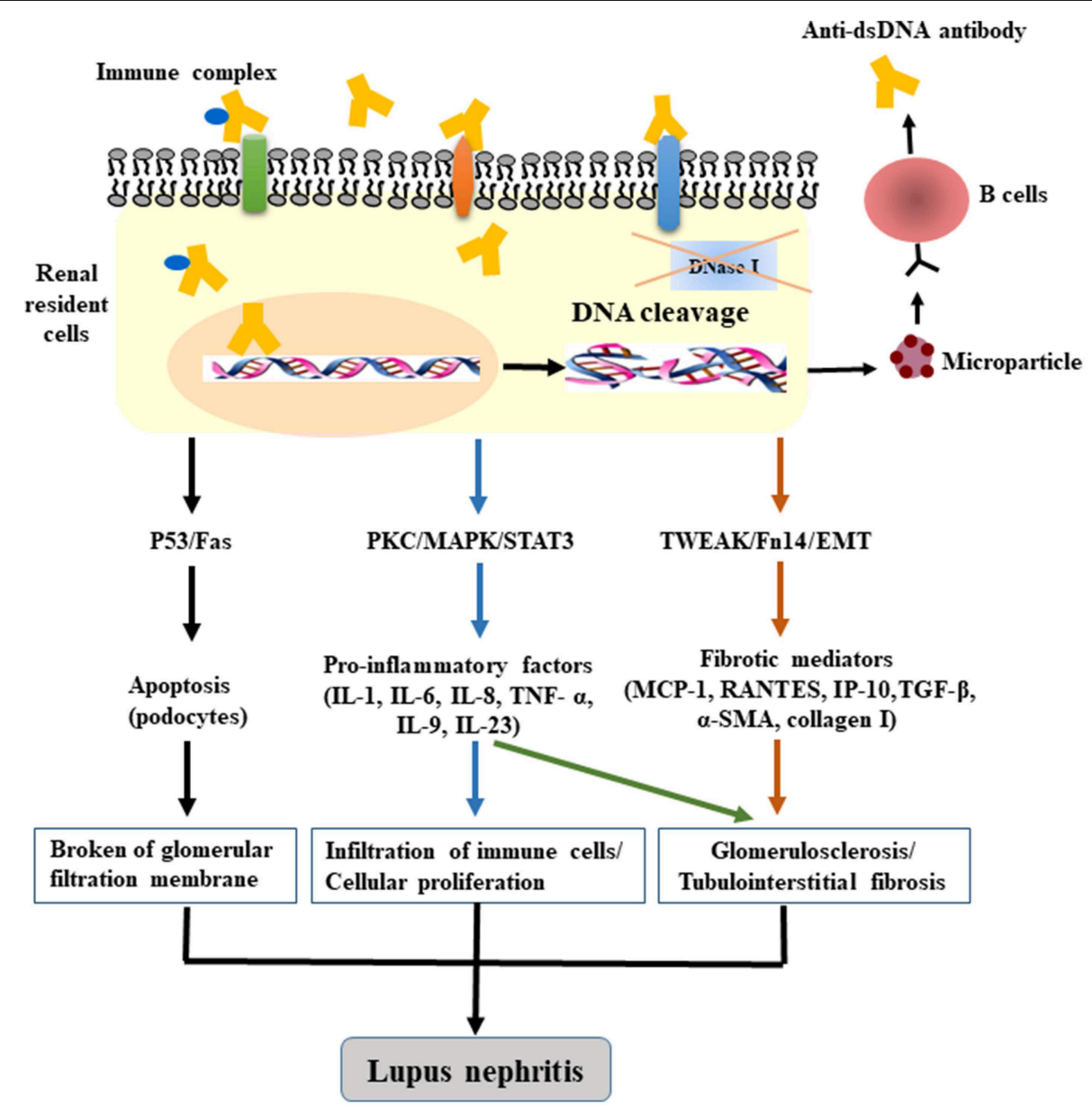

FIGURE 1 | The pathogenic mechanism of anti-dsDNA antibodies in LN. After binding to DNA and non-DNA antigens, the penetrating anti-dsDNA antibodies relocate to the cytosol and cell nucleus, cause DNA fragmentation (accompanied by dysfunction of DNase), and induce apoptosis by regulating the gene expression of p53, Fas, or c-myc. The internalized anti-dsDNA antibodies enhance the expression of IL-6, IL-1 $\beta$, TNF- $\alpha$, and TGF- $\beta 1$, activate the PKC, MAPK, TWEAK/Fn14, and EMT signaling pathways, and trigger the fibrotic process. Local deposition of anti-dsDNA IgG-in combination with the secretion of inflammatory or profibrogenic cytokines as well as the recruitment of immune cells-is sufficient for the initiation of renal fibrosis in LN.

\section{Anti-dsDNA IgG Participates in Other Injuries}

Skin is frequently affected by SLE and can be the only affected organ. The serum positivity for an anti-dsDNA antibody is observed in only a subgroup of patients with cutaneous lupus erythematosus. The binding specificity of anti-DNA IgG to skin sections and keratinocytes has been observed in vitro, which can be promoted by ultraviolet light irradiation, resulting in keratinocyte apoptosis via antibody-dependent and cellmediated cytotoxicity $(33,99)$. The deposition of an immune complex at the dermoepidermal junction has been confirmed in both murine models and patients with serological positivity for anti-DNA IgG (33). Actually, the mild inflammatory response in combination with the presence of autoantibodies is necessary for further cross-reactions with collagen III, collagen IV, and SOCS1 and -8 for induction of antibody accumulation in skin tissue $(42,100)$. In addition to LN, the role of TWEAK/Fn14 signals in cutaneous lupus erythematosus has been discovered in murine lupus models $(87,101-103)$. Ultraviolet B irradiation promotes the anti-DNA IgG binding to keratinocytes as well as the expression of Fn14, which engages in an interplay with TWEAK and subsequently enriches the expression of proinflammatory factors and induces apoptosis $(33,103)$. These induced factors, including IL-6, IL-8, MCP-1, and RANTES (regulated upon activation, normal $\mathrm{T}$ cell expressed and secreted), further amplify the inflammatory responses by attracting immune cells (101).

Central nervous system (CNS) diseases are associated with a poor prognosis among patients with SLE and have been increasingly reported during the past decade. Neuropsychiatric complications occur in $30-40 \%$ of patients with SLE and may constitute the initial presentation or a flare (89). Antiphospholipid, anti-N-methyl-D-aspartate receptor (NMDAR), anti-ribosomal-P, and anti-dsDNA antibodies account for the progression of CNS disease (43). Anti-dsDNA antibodies can cross-react with NMDAR on neurons. An extracellular epitope has been identified near amino acid residue 369 of GlyN1 in 
NMDAR and decreases the density of the surface receptor, causing further neuronal disorders, such as abnormalities of cognition and memory $(43,44)$. Enriched serum anti-dsDNA and anti-NMDAR antibodies are associated with the emergence of neuropsychiatric lupus symptoms (45). Nevertheless, an increased titer of an anti-DNA antibody is not always consistent with neurological dysfunctions (104). The inconsistency may be due to the differences in cognitive assessments applied in diverse studies and the samples tested. The anti-NMDAR/dsDNA antibodies can generate and gain access to the brain tissue after the destruction of the blood-brain barrier, leading to neuronal cell death and abnormalities in mice (45). Injection of mouse brains with an anti-DNA antibody (R4A) causes apoptosis of hippocampal cells (105). Besides, we observed enhanced expression of proinflammatory factors as well as abnormal cognition and behavior in wild-type mice, while the cognition and integrity of the blood-brain barrier are attenuated in Fn14deficient mice, indicating the amplification of TWEAK/Fn14 signals in the pathogenesis of CNS diseases (106).

\section{The Constant Region Contributes to the Antigenic Specificity and Pathogenicity of Anti-DNA Antibodies}

Classically, the variable region is the only part of an antibody that is credited with the antigenic specificity, whereas the functions of antibodies are determined by the constant region. These two domains are believed to be structurally and functionally independent. However, the specificity and affinity of antibodies are believed to be determined by both regions but not solely by the variable one (107). The variety of isotypes of anti-DNA antibodies is generated through the isotype switch recombination in the sequence from $\operatorname{IgM}$ to $\operatorname{IgG}$, whose variable regions are identical to those of the initial antibody. Particular subclasses of anti-DNA antibodies are more closely associated with a pathogenic potential (47). In lupus patients, serum anti-DNA IgG1 is always elevated before the occurrence of renal relapse, while $\operatorname{IgG} 2 \mathrm{a}, \operatorname{IgG} 2 \mathrm{~b}$, and $\operatorname{IgG} 3$ are more frequently eluted from kidneys with active nephritis $(78,108)$. In addition, different IgG subclasses with similar specificity for DNA show a remarkable difference in the binding properties for basement membranes, the formation of immune-complex deposits, and the severity of the induced proteinuria (109).

To validate the association between subclasses and pathogenicity, we found that different isotypes of anti-dsDNA antibodies differ from each other in the recognition specificity of nuclear and renal antigens when we generated a panel of murine anti-DNA antibodies (IgM, IgG1, IgG2a, IgG2b, and IgG3), which contain identical variable-joining-diversity (VDJ) regions, suggesting that the effect of the constant region on antibody binding is directly associated with autoimmunity (34). In fact, the factors responsible for the pathogenicity of anti-DNA antibodies are diverse, including their binding avidity for DNA, cross-reactivity for self-antigens, characteristics of the idiotype, and localization of specific amino acid residues in CDRs (110). Additionally, the diverse subclasses of autoantibodies that determine the complement fixation and Fc binding are crucial in LN. The isotypes that form the immune complex can fix complement-in a process involving IgG1 and IgG3 in humans and IgG2a and IgG2b in mice-upregulated in the renal glomerulus $(111,112)$. IgG2a and IgG2b manifest the most robust complement activity and binding affinity for triggering Fc receptors III and IV and are the most potent autoantibodies during the mediation of hemolytic anemia in vivo (108). Although IgG2a is the predominant subclass among IgG-reactive IgGs and is present as the most pathological subclass in murine lupus models (113), IgG3 derived from MRL/lpr mice is crucial for the spontaneous glomerular disruption and dysfunction (109). Besides, the constant region of antibodies affects their binding ability toward DNA and histones not only by varying the environments of their paratopes but also by altering their secondary structures $(34,114)$. Nevertheless, the prognostic value of these subclasses of anti-dsDNA antibodies remains to be illustrated.

\section{The Catalytic Properties of Anti-dsDNA IgG}

The first IgG antibody with DNA-related catalytic activity in SLE was found in 1992 (115). Antibodies binding to nucleoprotein complexes, to DNA, and enzymes that account for nucleic acid metabolism may acquire the feature of the primary antigen-catalytic activity. The amino acid residues of catalytic anti-dsDNA antibodies and DNA enzymes may have similarities because anti-dsDNA antibodies in patients with SLE have been shown to hydrolyze plasmid DNA (116-118). The catalytic activity of anti-DNA antibodies is associated with the binding of magnesium and calcium ions, and their cytotoxicity results from the hydrolysis of nuclear matrix proteins (Figure 2) (116). Moreover, the variety of light chains of anti-DNA IgG, the tolerance of temperature, optimum $\mathrm{pH}$, and hydrolysis rate are thought to be responsible for distinct activities of anti-DNA antibodies and their capacity for DNA hydrolysis (119).

In the sequence analysis of anti-DNA antibodies from humans and mice, there is a high frequency of somatic mutations in the $\mathrm{VH}$ and VL sequences of anti-dsDNA IgG with high affinity (53). Such somatic mutations result in a higher proportion of certain amino acids, especially arginine, asparagine, lysine, and tyrosine in the CDRs; this phenomenon promotes the formation of electrostatic interactions and hydrogen bonds between these amino acids and DNA (53). In our study, anti-dsDNA antibodies of various isotypes (PL9-11 clone) that share identical variable regions but different constant regions could cleave not only dsDNA but also peptide antigens depending on the isotype, e.g., the ALWPPNLHAWVP peptide, indicating that the catalytic cleavage of DNA can be regarded as a natural property of these antibodies (120). The specific affinity of anti-DNA antibodies to antigens probably determines the possibility of catalysis, but not the catalytic efficiency of the reaction. Although antibodies derived from various sources contain similar variable-chain sequences, these antibodies have different catalytic activities. In addition, in the context of this specific autoantibody system, a specific mutation results in the reduction of DNA binding as well as weakened catalytic activity (121). The DNA binding and hydrolytic activities of anti-DNA antibodies are well-conserved 


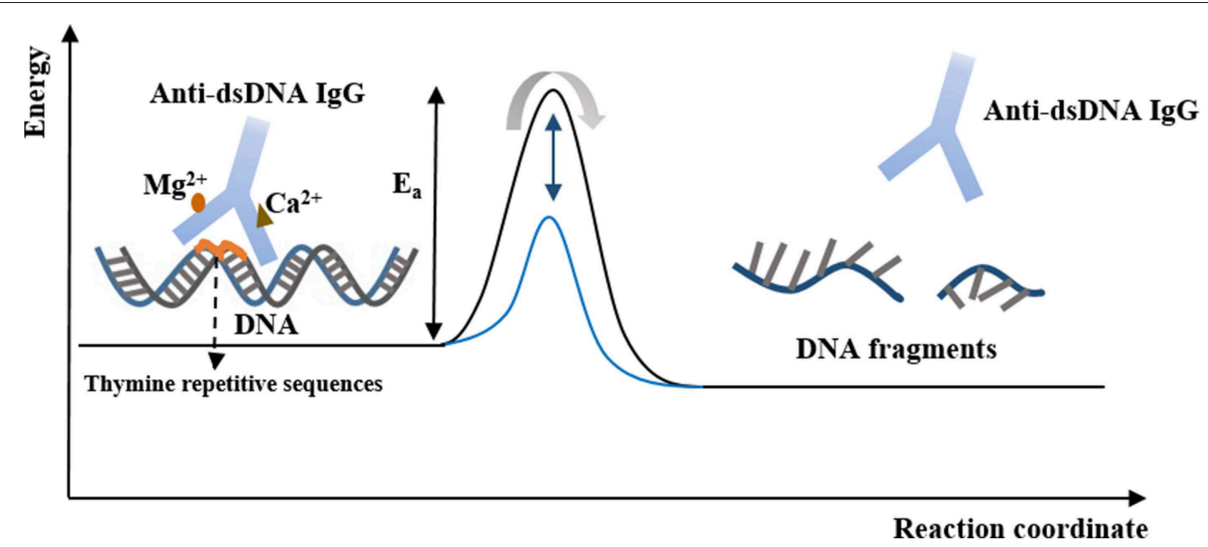

FIGURE 2 | The catalytic properties of anti-dsDNA IgG. Anti-dsDNA IgG binds to DNA at the thymine repetitive sequences via tyrosine side chains within a hydrophobic pocket. Hydrolysis of DNA is an energy-intensive process and can be activated by the binding of $\mathrm{Ca}^{2+}$ and Mg ${ }^{2+}$. After binding to DNA, the active site of IgG is converted to a transition state, and the DNA fragments are produced and released. At this point, the free lgG binds to another DNA molecule and begins its new cycle, in which IgG stabilizes the transition state of the reaction and lowers the activation energy, and thereby increases the rate of the reaction.

in both VH and VL. The catalytic characteristics of anti-DNA antibodies are isotype-dependent, and constant regions have an influence on the autoantibody-antigen interaction presumably by modifying the secondary structure of antibodies $(34,114,120)$.

\section{THE BLOCKADE OF PATHOGENIC ANTI-DSDNA IGG}

\section{An iDC Vaccine Suppresses the Production of Anti-dsDNA IgG}

This therapeutic strategy against SLE is focused on eliminating or controlling active B cells that offer limited benefits but hamper the advancement of treatment for $\operatorname{SLE}(122,123)$. Recently, the significance of iDCs in the induction of clonal anergy and immune tolerance was highlighted. iDCs participate in the anergy of $\mathrm{T}$ cells by inducing the apoptosis and promoting the differentiation of Treg cells because the expression of costimulatory factors and MHC molecules on the surface of iDCs decrease considerably (124). As a key cytokine for inhibiting excessive immune responses, IL-10 can reduce the production of relevant cytokines (such as TNF- $\alpha$ and IL-1 $\beta$,) as well as increase production of inhibitory factors (such as programmed death ligand 1) in DCs, thereby inhibiting Treg responses and the function of effector $\mathrm{T}$ cells (125-127). Among these factors, programmed death ligand 1 in combination with TGF$\beta$ is particularly important for promoting the conversion of CD4+ T cells to Foxp3+ CD4+ Treg cells, whereas blockade of programmed death ligand 1 can reduce anti-dsDNA IgG production and immune-complex formation in lupus-prone mice by suppressing the synthesis of IL-10 in CD4+ Treg and $\mathrm{B}$ cells, thus further validating the therapeutic potential of iDCs $(128,129)$. After the induction of clonal anergy, $\mathrm{T}$ cells fail to bind to cognate antigens that are presented by DCs.

The iDCs exert weaker activating effects on $\mathrm{T}$ cells by expressing lower amounts of costimulatory cytokines, including IL-6 and IL-12 in patients with SLE; this observation is consistent with iDCs' effects in lupus-like mice where iDCs lower the responses of Th1/Th2 cells and thus inhibit the secretion of IL-2, IL-4, IL-12, and interferon $\gamma$ and the formation of anti-dsDNA IgG (130-132). Besides, iDCs from hemopoietic stem cells can be loaded with nuclear antigens, thereby serving as a live cell vaccine $(131,132)$. Thus, iDCs are emerging as promising immunomodulators in SLE. Nonetheless, there are many challenges regarding the appropriate production protocols and administration route and timing of an iDC vaccine. Moreover, the exact mechanism by which iDCs interact with Treg cells, B cells, and other cells, as well as the possible side effects are largely unclear. Therefore, the translational application of the iDC vaccine in clinical settings requires multidisciplinary efforts.

\section{DNA-Mimicking Peptides Block the Binding of Anti-dsDNA IgG}

Based on the interactions between self-antigens and anti-dsDNA antibodies, novel therapeutic peptides that bind to autoantibodies have attracted increasing attention. These peptides can be synthesized by combining desired amino acid residues or by chemical modification of certain sequences, to ensure higher activity and specificity. To date, therapeutic peptides have proven to be effective against experimental autoimmune diseases, for example, rheumatoid arthritis and multiple sclerosis (133). Moreover, some therapeutic peptides have been demonstrated to prevent anti-dsDNA antibodies from binding and reacting with target antigens and tissues in the studies on SLE.

Peptide DWEYS (D/E W D/E Y S/G), a part of NMDAR expressed on neurons, has been shown to bind to anti-dsDNA antibodies, thereby disrupting the neurotoxicity of anti-DNA antibodies through the NMDAR-activated pathway, in which circulating antibodies penetrate the hippocampal pyramidal cells followed by impairment of spatial cognition (134). In addition, peptide DWEYS can prevent the proliferation of both $\mathrm{B}$ cells and $\mathrm{T}$ cells and ameliorate the production of 
anti-DNA IgG and proteinuria in lupus mice by selectively suppressing the autoreactive B lymphocytes via cross-reaction with the immunoglobulin receptors on B cells (135). Although the DWEYS peptide is certainly beneficial for therapeutic applications owing to the small molecular weight and nonimmunogenicity, it is not highly useful due to its short half-life.

FISLE-412, an analog of a reduced protease inhibitor for the human immunodeficiency virus, has the potential to block DNA recognition of anti-dsDNA antibodies (136). FISLE-412 can reduce glomerular deposition of IgG, protect kidneys from damage, and suppress the onset of SLE in murine models. Moreover, the FISLE-12-bound anti-dsDNA antibodies exert no neurotoxic effects on C57BL/6 mice; this finding shows a greater neuroprotective effect than that of the DWEYS peptide (136). As compared with DWEYS, FISLE412 has higher affinity and a more stable structure and is more suitable for oral administration (136). The study on the structure-activity relationship of several synthesized analogs of FISLE-412 has revealed that the hydrophobic portion is the key region for this therapeutic function (137). In addition, the quinaldic region contributes to the binding activity of FISLE-412 (137).

ASPVTARVLWKASHV is a 15-mer peptide selected by purified polyclonal anti-dsDNA IgG in lupus patients and can inhibit antigen-IgG binding (138). ALW (ALWPPNLHAWVP) is a 12-mer peptide mimic originating from a panel of murine anti-DNA IgG isotypes; it can bind to all four IgG isotypes and prevent IgG binding to DNA or glomerular antigens (3). ALW is physiologically stable and resistant to oxidation, cyclization, and degradation because it lacks a sequence of certain amino acid residues (3). Although ALW and its mimics are receiving increasing attention as therapeutic molecules with less toxicity for lupus patients, a combination of different peptides should be taken into consideration because of the variability and crossreactivity of anti-DNA antibodies. In addition, peptides have low toxicity when administered orally or subcutaneously and would not be expected to be immunogenic.

pCons (FIEWNKLRFRQGLEW) is a 15-mer peptide derived from murine anti-dsDNA antibodies; it exerts therapeutic effects by preventing antibody-antigen binding (139). pCons significantly enhances the survival rate and alleviates glomerulonephritis in NZB/W lupus mice; this beneficial action may be mediated by the regulation of $\mathrm{T}$-cell autoreactivity $(140,141)$. The protective effects have been validated in lupus-prone mice treated with a B lymphocyte gene vaccine that codes for IgG1 Fc-pCons, where early and repeated administration of the vaccine delayed proteinuria and enhanced survival remarkably as well as the expansion of Foxp3+ CD4+ Treg cells (142).

hCDR1 (GYYWSWIRQPPGKGEEWIG) is a 19-mer peptide that is based on CDR1 sequences from human anti-DNA antibodies. hCDR1 has suppressive effects on $\mathrm{T}$ cells by reducing apoptosis of $\mathrm{T}$ cells with less secretion of interferon- $\gamma$ and upregulation of IL-10 in lupus-prone mice (143). The effects of hCDR1 on B cells are also associated with downregulated levels of anti-DNA antibodies in lupus-prone mice (144). In an early clinical study, weekly subcutaneous administration of different doses of hCDR1 (Edratide)--0.5, 1.0, and $2.5 \mathrm{mg}-$ was found to be effective in ameliorating the manifestations and in downregulating the production of proinflammatory and proapoptotic cytokines in SLE patients; the affected proapoptotic proteins include IL- $1 \beta$, TNF- $\alpha$, IFN- $\gamma$, IL-10, caspase 3, and caspase 8 (145). The efficacy of hCDR1 in the treatment of SLE was questioned because of the limited sample size ( 9 patients) and disease severity from mild to moderate among the patients. In a later clinical phase II trial, the injection of hCDR1 once a week at a dose of $0.5 \mathrm{mg}$ in SLE patients with a larger sample size (340 patients) was found to be safe and effective, with a decreased SLE disease activity index (SLEDAI-2K). However, there was no remarkable difference between the hCDR1 group and placebo group. In addition, the shortest course of efficacy proven by this trial was nearly 1 year, and the primary endpoint was not reached; this factor may be responsible for the insignificance of the therapeutic effects (146). Thus, a longer-term and appropriate endpoint should be scheduled in later studies on hCDR1.

\section{MAIN CONCLUSIONS AND FURTHER INVESTIGATIONS}

Anti-dsDNA antibodies, the hallmark of SLE, constitute a potent parameter for classifying and diagnosing SLE. Their contribution to damage to the kidneys, skin, and brain in SLE has been welldocumented. The production of anti-dsDNA antibodies results from combining multiple factors, including abnormalities of dendritic cells, $\mathrm{B}$ cells, or $\mathrm{T}$ cells and deficiency of a DNase that leads to failure of cleaning released nuclear materials; however, it still need further studies. The effects of penetrating autoantibodies on triggering a complicated inflammatory and fibrotic process underlie the role of anti-DNA antibodies in damaging target cells and organs. The pathogenicity of antibodies highlights the promising therapeutic potential of DNA-mimicking peptides that react with these autoantibodies in SLE, which can ameliorate the manifestations of SLE in murine models. However, the clinical trials progress slowly in which the timing, dosages, route of administration, alteration of bioactivity, and possible adverse effects of such peptides should be taken into account for developing more efficient therapies for SLE.

\section{AUTHOR CONTRIBUTIONS}

YX conceived this paper. XW wrote this manuscript. XW and YX read and approved the final manuscript.

\section{FUNDING}

This study was supported by the National Natural Science Foundation of China (Projects No.81472876 and No.81874241) and the Fundamental Research Funds for the Central Universities (No.2015qngz01). 


\section{REFERENCES}

1. Rekvig OP. Anti-dsDNA antibodies as a classification criterion and a diagnostic marker for systemic lupus erythematosus: critical remarks. Clin Exp Immunol. (2015) 179:5-10. doi: 10.1111/cei.12296

2. Hoeppe S, Schreiber TD, Planatscher H, Zell A, Templin MF, Stoll D, et al. Targeting peptide termini, a novel immunoaffinity approach to reduce complexity in mass spectrometric protein identification. Mol Cell Proteomics. (2011) 10:M110.002857. doi: 10.1074/mcp.M110.002857

3. Xia Y, Eryilmaz E, Der E, Pawar RD, Guo X, Cowburn D, et al. A peptide mimic blocks the cross-reaction of anti-DNA antibodies with glomerular antigens. Clin Exp Immunol. (2016) 183:369-79. doi: 10.1111/cei.12734

4. Mistry P, Kaplan MJ. Cell death in the pathogenesis of systemic lupus erythematosus and lupus nephritis. Clin Immunol. (2017) 185:59-73. doi: 10.1016/j.clim.2016.08.010

5. Barnado A, Crofford LJ, Oates JC. At the bedside: neutrophil extracellular traps (NETs) as targets for biomarkers and therapies in autoimmune diseases. J Leukoc Biol. (2016) 99:265-78. doi: 10.1189/jlb.5BT0615-234R

6. Magna M, Pisetsky DS. The alarmin properties of DNA and DNA-associated nuclear proteins. Clin Ther. (2016) 38:1029-41. doi: 10.1016/j.clinthera.2016.02.029

7. Mackern-Oberti JP, Llanos C, Riedel CA, Bueno SM, Kalergis AM. Contribution of dendritic cells to the autoimmune pathology of systemic lupus erythematosus. Immunology. (2015) 146:497-507. doi: $10.1111 /$ imm. 12504

8. Bave U, Magnusson M, Eloranta ML, Perers A, Alm GV, Ronnblom L. Fc $\gamma$ RIIa is expressed on natural IFN- $\alpha$-producing cells (plasmacytoid dendritic cells) and is required for the IFN- $\alpha$ production induced by apoptotic cells combined with lupus IgG. J Immunol. (2003) 171:3296-302. doi: 10.4049/jimmunol.171.6.3296

9. Gleisner MA, Reyes P, Alfaro J, Solanes P, Simon V, Crisostomo N, et al. Dendritic and stromal cells from the spleen of lupic mice present phenotypic and functional abnormalities. Mol Immunol. (2013) 54:423-34. doi: 10.1016/j.molimm.2013.01.011

10. Sakata K, Nakayamada S, Miyazaki Y, Kubo S, Ishii A, Nakano K, et al. Upregulation of TLR7-mediated IFN- $\alpha$ production by plasmacytoid dendritic cells in patients with systemic lupus erythematosus. Front Immunol. (2018) 9:1957. doi: 10.3389/fimmu.2018.01957

11. Wang Y, Liang J, Qin H, Ge Y, Du J, Lin J, et al. Elevated expression of miR-142-3p is related to the pro-inflammatory function of monocytederived dendritic cells in SLE. Arthritis Res Ther. (2016) 18:263. doi: 10.1186/s13075-016-1158-Z

12. Santiago-Raber ML, Baudino L, Izui S. Emerging roles of TLR7 and TLR9 in murine SLE. J Autoimmun. (2009) 33:231-8. doi: 10.1016/j.jaut.2009.10.001

13. Santiago-Raber ML, Dunand-Sauthier I, Wu T, Li QZ, Uematsu S, Akira $S$, et al. Critical role of TLR7 in the acceleration of systemic lupus erythematosus in TLR9-deficient mice. J Autoimmun. (2010) 34:339-48. doi: 10.1016/j.jaut.2009.11.001

14. Jackson SW, Scharping NE, Kolhatkar NS, Khim S, Schwartz MA, Li QZ, et al. Opposing impact of B cell-intrinsic TLR7 and TLR9 signals on autoantibody repertoire and systemic inflammation. J Immunol. (2014) 192:4525-32. doi: 10.4049/jimmunol.1400098

15. Celhar T, Magalhaes R, Fairhurst AM. TLR7 and TLR9 in SLE: when sensing self goes wrong. Immunol Res. (2012) 53:58-77. doi: 10.1007/s12026-012-8270-1

16. Chen Q, Sun L, Chen ZJ. Regulation and function of the cGAS-STING pathway of cytosolic DNA sensing. Nat Immunol. (2016) 17:1142-9. doi: $10.1038 /$ ni.3558

17. Pohar J, Yamamoto C, Fukui R, Cajnko MM, Miyake K, Jerala R, et al. Selectivity of human TLR9 for double CPG motifs and implications for the recognition of genomic DNA. J Immunol. (2017) 198:2093-104. doi: 10.4049/jimmunol.1600757

18. Chang NH, Li TT, Kim JJ, Landolt-Marticorena C, Fortin PR, Gladman $\mathrm{DD}$, et al. Interferon- $\alpha$ induces altered transitional B cell signaling and function in Systemic Lupus Erythematosus. J Autoimmun. (2015) 58:100-10. doi: 10.1016/j.jaut.2015.01.009

19. Golding A, Rosen A, Petri M, Akhter E, Andrade F. Interferon-alpha regulates the dynamic balance between human activated regulatory and effector T cells: implications for antiviral and autoimmune responses. Immunology. (2010) 131:107-17. doi: 10.1111/j.1365-2567.2010.03280.x

20. Wang JH. The role of activation-induced deaminase in antibody diversification and genomic instability. Immunol Res. (2013) 55:287-97. doi: 10.1007/s12026-012-8369-4

21. Biswas PS, Aggarwal R, Levesque MC, Maers K, Ramani K. Type I interferon and $\mathrm{T}$ helper 17 cells co-exist and co-regulate disease pathogenesis in lupus patients. Int J Rheum Dis. (2015) 18:646-53. doi: 10.1111/1756-185X.12636

22. Mudd PA, Teague BN, Farris AD. Regulatory $\mathrm{T}$ cells and systemic lupus erythematosus. Scand J Immunol. (2006) 64:211-8. doi: 10.1111/j.1365-3083.2006.01808.x

23. Marshak-Rothstein A. Toll-like receptors in systemic autoimmune disease. Nat Rev Immunol. (2006) 6:823-35. doi: 10.1038/nri1957

24. Chen M, Zhang W, Xu W, Zhang F, Xiong S. Blockade of TLR9 signaling in B cells impaired anti-dsDNA antibody production in mice induced by activated syngenic lymphocyte-derived DNA immunization. Mol Immunol. (2011) 48:1532-9. doi: 10.1016/j.molimm.2011.04.016

25. Henault J, Martinez J, Riggs JM, Tian J, Mehta P, Clarke L, et al. Noncanonical autophagy is required for type I interferon secretion in response to DNA-immune complexes. Immunity. (2012) 37:986-97. doi: 10.1016/j.immuni.2012.09.014

26. Liang Q, Seo GJ, Choi YJ, Kwak MJ, Ge J, Rodgers MA, et al. Crosstalk between the cGAS DNA sensor and Beclin-1 autophagy protein shapes innate antimicrobial immune responses. Cell Host Microbe. (2014) 15:22838. doi: 10.1016/j.chom.2014.01.009

27. Li B, Yue Y, Dong C, Shi Y, Xiong S. Blockade of macrophage autophagy ameliorates activated lymphocytes-derived DNA induced murine lupus possibly via inhibition of proinflammatory cytokine production. Clin Exp Rheumatol. (2014) 32:705-14.

28. Hu Z, Leppla SH, Li B, Elkins CA. Antibodies specific for nucleic acids and applications in genomic detection and clinical diagnostics. Expert Rev Mol Diagn. (2014) 14:895-916. doi: 10.1586/14737159.2014.931810

29. Akberova NI, Zhmurov AA, Nevzorova TA, Litvinov RI. An anti-DNA antibody prefers damaged dsDNA over native. J Biomol Struct Dyn. (2017) 35:219-32. doi: 10.1080/07391102.2015.1128979

30. Yung S, Cheung KF, Zhang Q, Chan TM. Anti-dsDNA antibodies bind to mesangial annexin II in lupus nephritis. J Am Soc Nephrol. (2010) 21:191227. doi: 10.1681/ASN.2009080805

31. Bassyouni IH, El-Shazly R, Azkalany GS, Zakaria A, Bassyouni RH. Clinical significance of soluble-endoglin levels in systemic lupus erythematosus: possible association with anti-phospholipid syndrome. LUPUS. (2012) 21:1565-70. doi: 10.1177/0961203312460115

32. Yung S, Chan TM. Mechanisms of kidney injury in lupus nephritis - the role of anti-dsDNA antibodies. Front Immunol. (2015) 6:475. doi: 10.3389/fimmu.2015.00475

33. Dong Y, Zhang Y, Xia L, Wang P, Chen J, Xu M, et al. The deposition of antiDNA IgG contributes to the development of cutaneous lupus erythematosus. Immunol Lett. (2017) 191:1-9. doi: 10.1016/j.imlet.2017.09.003

34. Xia Y, Pawar RD, Nakouzi AS, Herlitz L, Broder A, Liu K, et al. The constant region contributes to the antigenic specificity and renal pathogenicity of murine anti-DNA antibodies. J Autoimmun. (2012) 39:398411. doi: 10.1016/j.jaut.2012.06.005

35. Krishnan MR, Wang C, Marion TN. Anti-DNA autoantibodies initiate experimental lupus nephritis by binding directly to the glomerular basement membrane in mice. Kidney Int. (2012) 82:184-92. doi: 10.1038/ki.2011.484

36. Franchin G, Son M, Kim SJ, Ben-Zvi I, Zhang J, Diamond B. AntiDNA antibodies cross-react with C1q. J Autoimmun. (2013) 44:34-9. doi: 10.1016/j.jaut.2013.06.002

37. Hirohata S. Anti-ribosomal $\mathrm{P}$ antibodies and lupus nephritis. Clin Exp Nephrol. (2011) 15:471-7. doi: 10.1007/s10157-011-0462-9

38. Zou X, Cheng H, Zhang Y, Fang C, Xia Y. The antigen-binding fragment of anti-double-stranded DNA IgG enhances F-actin formation in mesangial cells by binding to alpha-actinin-4. Exp Biol Med (Maywood). (2012) 237:1023-31. doi: 10.1258/ebm.2012.012033

39. Li QZ, Xie C, Wu T, Mackay M, Aranow C, Putterman C, et al. Identification of autoantibody clusters that best predict lupus disease activity using glomerular proteome arrays. J Clin Invest. (2005) 115:3428-39. doi: 10.1172/JCI23587 
40. Amital H, Heilweil M, Ulmansky R, Szafer F, Bar-Tana R, Morel L, et al. Treatment with a laminin-derived peptide suppresses lupus nephritis. $J$ Immunol. (2005) 175:5516-23. doi: 10.4049/jimmunol.175.8.5516

41. Yung S, Ng CY, Ho SK, Cheung KF, Chan KW, Zhang Q, et al. Anti-dsDNA antibody induces soluble fibronectin secretion by proximal renal tubular epithelial cells and downstream increase of TGF- $\beta 1$ and collagen synthesis. J Autoimmun. (2015) 58:111-22. doi: 10.1016/j.jaut.2015. 01.008

42. Liu L, Xu G, Dou H, Deng GM. The features of skin inflammation induced by lupus serum. Clin Immunol. (2016) 165:4-11. doi: 10.1016/j.clim.2016.02.007

43. Selmi C, Barin JG, Rose NR. Current trends in autoimmunity and the nervous system. J Autoimmun. (2016) 75:20-9. doi: 10.1016/j.jaut.2016.08.005

44. Hoftberger R. Neuroimmunology: an expanding frontier in autoimmunity. Front Immunol. (2015) 6:206. doi: 10.3389/fimmu.2015.00206

45. Kowal C, Diamond B. Aspects of CNS lupus: mouse models of anti-NMDA receptor antibody mediated reactivity. Methods Mol Biol. (2012) 900:181206. doi: 10.1007/978-1-60761-720-4_9

46. Park H, Kim M, Kim HJ, Lee Y, Seo Y, Pham CD, et al. Heparan sulfate proteoglycans (HSPGs) and chondroitin sulfate proteoglycans (CSPGs) function as endocytic receptors for an internalizing antinucleic acid antibody. Sci Rep. (2017) 7:14373. doi: 10.1038/s41598-017-1 4793-z

47. Villalta D, Bizzaro N, Bassi N, Zen M, Gatto M, Ghirardello A, et al. AntidsDNA antibody isotypes in systemic lupus erythematosus: IgA in addition to IgG anti-dsDNA help to identify glomerulonephritis and active disease. PLoS ONE. (2013) 8:e71458. doi: 10.1371/journal.pone.0071458

48. Gronwall C, Akhter E, Oh C, Burlingame RW, Petri M, Silverman GJ. IgM autoantibodies to distinct apoptosis-associated antigens correlate with protection from cardiovascular events and renal disease in patients with SLE. Clin Immunol. (2012) 142:390-8. doi: 10.1016/j.clim.2012.01.002

49. Umiker BR, McDonald G, Larbi A, Medina CO, Hobeika E, Reth M, et al. Production of IgG autoantibody requires expression of activation-induced deaminase in early-developing B cells in a mouse model of SLE. Eur J Immunol. (2014) 44:3093-108. doi: 10.1002/eji.201344282

50. McDonald G, Medina CO, Pilichowska M, Kearney JF, Shinkura R, Selsing E, et al. Accelerated systemic autoimmunity in the absence of somatic hypermutation in 564Igi: A mouse model of systemic lupus with knocked-in heavy and light chain genes. Front Immunol. (2017) 8:1094. doi: 10.3389/fimmu.2017.01094

51. Diaz M. The role of activation-induced deaminase in lupus nephritis. Autoimmunity. (2013) 46:115-20. doi: 10.3109/08916934.2012.750303

52. Jiang C, Zhao ML, Scearce RM, Diaz M. Activation-induced deaminasedeficient MRL/lpr mice secrete high levels of protective antibodies against lupus nephritis. Arthritis Rheum. (2011) 63:1086-96. doi: 10.1002/art.30230

53. Schroeder K, Herrmann M, Winkler TH. The role of somatic hypermutation in the generation of pathogenic antibodies in SLE. Autoimmunity. (2013) 46:121-7. doi: 10.3109/08916934.2012.7 48751

54. Richardson C, Chida AS, Adlowitz D, Silver L, Fox E, Jenks SA, et al. Molecular basis of 9G4 B cell autoreactivity in human systemic lupus erythematosus. J Immunol. (2013) 191:4926-39. doi: 10.4049/jimmunol.1202263

55. Hatada Y, Kashiwakura J, Hayama K, Fujisawa D, Sasaki-Sakamoto T, Terui $\mathrm{T}$, et al. Significantly high levels of anti-dsDNA immunoglobulin E in sera and the ability of dsDNA to induce the degranulation of basophils from chronic urticaria patients. Int Arch Allergy Immunol. (2013) 161(Suppl. 2):154-8. doi: $10.1159 / 000350388$

56. Dema B, Pellefigues C, Hasni S, Gault N, Jiang C, Ricks TK, et al. Autoreactive $\operatorname{IgE}$ is prevalent in systemic lupus erythematosus and is associated with increased disease activity and nephritis. PLOS ONE. (2014) 9:e90424. doi: 10.1371/journal.pone.0090424

57. Pan N, Amigues I, Lyman S, Duculan R, Aziz F, Crow MK, et al. A surge in anti-dsDNA titer predicts a severe lupus flare within six months. LUPUS. (2014) 23:293-8. doi: 10.1177/0961203313515763

58. Uccellini MB, Busto P, Debatis M, Marshak-Rothstein A, Viglianti GA. Selective binding of anti-DNA antibodies to native dsDNA fragments of differing sequence. Immunol Lett. (2012) 143:85-91. doi: 10.1016/j.imlet.2012.01.003

59. Compagno M, Jacobsen S, Rekvig OP, Truedsson L, Heegaard NH, Nossent J, et al. Low diagnostic and predictive value of anti-dsDNA antibodies in unselected patients with recent onset of rheumatic symptoms: results from a long-term follow-up Scandinavian multicentre study. Scand J Rheumatol. (2013) 42:311-6. doi: 10.3109/03009742.2013.765032

60. Andrejevic S, Jeremic I, Sefik-Bukilica M, Nikolic M, Stojimirovic B, BonaciNikolic B. Immunoserological parameters in SLE: high-avidity anti-dsDNA detected by ELISA are the most closely associated with the disease activity. Clin Rheumatol. (2013) 32:1619-26. doi: 10.1007/s10067-013-2330-3

61. Panza F, Alcaro MC, Petrelli F, Angelotti F, Pratesi F, Rovero P, et al. A novel DNA/histone H4 peptide complex detects autoantibodies in systemic lupus erythematosus sera. Arthritis Res Ther. (2016) 18:220. doi: 10.1186/s13075-016-1117-8

62. Xia YM, Ding GH, Xu SZ, Jiang S, Yang HX, Xiong LY. Induction of lupus-like renal damages by double stranded DNA derived from Trypanosoma equiperdum. Chin Med J. (2006) 119:1753-6. doi: 10.1097/00029330-200610020-00015

63. Poulsen NN, Pedersen ME, Ostergaard J, Petersen NJ, Nielsen CT, Heegaard $\mathrm{NH}$, et al. Flow-induced dispersion analysis for probing anti-dsDNA antibody binding heterogeneity in systemic lupus erythematosus patients: toward a new approach for diagnosis and patient stratification. Anal Chem. (2016) 88:9056-61. doi: 10.1021/acs.analchem.6b01741

64. Mannik M, Merrill CE, Stamps LD, Wener MH. Multiple autoantibodies form the glomerular immune deposits in patients with systemic lupus erythematosus. J Rheumatol. (2003) 30:1495-504.

65. Waters ST, McDuffie M, Bagavant H, Deshmukh US, Gaskin F, Jiang C, et al. Breaking tolerance to double stranded DNA, nucleosome, and other nuclear antigens is not required for the pathogenesis of lupus glomerulonephritis. $J$ Exp Med. (2004) 199:255-64. doi: 10.1084/jem.20031519

66. Mjelle JE, Rekvig OP, Van Der Vlag J, Fenton KA. Nephritogenic antibodies bind in glomeruli through interaction with exposed chromatin fragments and not with renal cross-reactive antigens. Autoimmunity. (2011) 44:373-83. doi: 10.3109/08916934.2010.541170

67. Marschall AL, Zhang C, Frenzel A, Schirrmann T, Hust M, Perez F, et al. Delivery of antibodies to the cytosol: debunking the myths. MAbs. (2014) 6:943-56. doi: 10.4161/mabs. 29268

68. Im SR, Im SW, Chung HY, Pravinsagar P, Jang YJ. Cell- and nuclearpenetrating anti-dsDNA autoantibodies have multiple arginines in CDR3 of $\mathrm{VH}$ and increase cellular level of pERK and Bcl-2 in mesangial cells. Mol Immunol. (2015) 67(2 Pt B):377-87. doi: 10.1016/j.molimm.2015.06.025

69. Weisbart RH, Chan G, Jordaan G, Noble PW, Liu Y, Glazer PM, et al. DNAdependent targeting of cell nuclei by a lupus autoantibody. Sci Rep. (2015) 5:12022. doi: $10.1038 /$ srep 12022

70. Zannikou M, Bellou S, Eliades P, Hatzioannou A, Mantzaris MD, Carayanniotis G, et al. DNA-histone complexes as ligands amplify cell penetration and nuclear targeting of anti-DNA antibodies via energy-independent mechanisms. Immunology. (2016) 147:73-81. doi: 10.1111/imm. 12542

71. Stearns NA, Pisetsky DS. The role of monogamous bivalency and Fc interactions in the binding of anti-DNA antibodies to DNA antigen. Clin Immunol. (2016) 166-7:38-47. doi: 10.1016/j.clim.2016.04.004

72. Zhang H, Zhao C, Wang S, Huang Y, Wang H, Zhao J, et al. Anti-dsDNA antibodies induce inflammation via endoplasmic reticulum stress in human mesangial cells. J Transl Med. (2015) 13:178. doi: 10.1186/s12967-015-0536-7

73. Song YC, Sun GH, Lee TP, Huang JC, Yu CL, Chen $\mathrm{CH}$, et al. Arginines in the CDR of anti-dsDNA autoantibodies facilitate cell internalization via electrostatic interactions. Eur J Immunol. (2008) 38:317890. doi: 10.1002/eji.200838678

74. Tangtanatakul P, Thammasate B, Jacquet A, Reantragoon R, Pisitkun T, Avihingsanon Y, et al. Transcriptomic profiling in human mesangial cells using patient-derived lupus autoantibodies identified miR-10a as a potential regulator of IL8. Sci Rep. (2017) 7:14517. doi: 10.1038/s41598-017-1 5160-8

75. Yung S, Tsang RC, Sun Y, Leung JK, Chan TM. Effect of human anti-DNA antibodies on proximal renal tubular epithelial cell cytokine expression: 
implications on tubulointerstitial inflammation in lupus nephritis. J Am Soc Nephrol. (2005) 16:3281-94. doi: 10.1681/ASN.2004110917

76. Yang J, Li Q, Yang X, Li M. Interleukin-9 is associated with elevated antidouble-stranded DNA antibodies in lupus-prone mice. Mol Med. (2015) 21:364-70. doi: 10.2119/molmed.2014.00237

77. Iurlaro R, Munoz-Pinedo C. Cell death induced by endoplasmic reticulum stress. FEBS J. (2016) 283:2640-52. doi: 10.1111/febs. 13598

78. Yap DY, Yung S, Zhang Q, Tang C, Chan TM. Serum level of proximal renal tubular epithelial cell-binding immunoglobulin $\mathrm{G}$ in patients with lupus nephritis. LUPUS. (2016) 25:46-53. doi: 10.1177/0961203315 598018

79. Kanapathippillai P, Hedberg A, Fenton CG, Fenton KA. Nucleosomes contribute to increase mesangial cell chemokine expression during the development of lupus nephritis. Cytokine. (2013) 62:244-52. doi: 10.1016/j.cyto.2013.03.016

80. Yung S, Zhang Q, Chau MK, Chan TM. Distinct effects of mycophenolate mofetil and cyclophosphamide on renal fibrosis in NZBWF1/J mice. Autoimmunity. (2015) 48:471-87. doi: 10.3109/08916934.2015.10 54027

81. Yung S, Ng CY, Au KY, Cheung KF, Zhang Q, Zhang C, et al. Binding of anti-dsDNA antibodies to proximal tubular epithelial cells contributes to renal tubulointerstitial inflammation. Clin Sci. (2017) 131:4967. doi: $10.1042 / C S 20160421$

82. Masum MA, Ichii O, Hosny Ali Elewa Y, Nakamura T, Otani Y, Hosotani M, et al. Overexpression of toll-like receptor 9 correlates with podocyte injury in a murine model of autoimmune membranoproliferative glomerulonephritis. Autoimmunity. (2018) 51:386-98. doi: 10.1080/08916934.2018.15 49234

83. Lu J, Kwan BC, Lai FM, Choi PC, Tam LS, Li EK, et al. Gene expression of TWEAK/Fn14 and IP-10/CXCR3 in glomerulus and tubulointerstitium of patients with lupus nephritis. Nephrology. (2011) 16:426-32. doi: $10.1111 / \mathrm{j} .1440-1797.2011 .0$ 1449.x

84. Gao HX, Campbell SR, Burkly LC, Jakubowski A, Jarchum I, Banas B, et al. TNF-like weak inducer of apoptosis (TWEAK) induces inflammatory and proliferative effects in human kidney cells. Cytokine. (2009) 46:24-35. doi: 10.1016/j.cyto.2008.12.001

85. Berzal S, Gonzalez-Guerrero C, Rayego-Mateos S, Ucero A, Ocana-Salceda C, Egido J, et al. TNF-related weak inducer of apoptosis (TWEAK) regulates junctional proteins in tubular epithelial cells via canonical NFkappaB pathway and ERK activation. J Cell Physiol. (2015) 230:1580-93. doi: $10.1002 / j c p .24905$

86. Liu Z, Xue L, Liu Z, Huang J, Wen J, Hu J, et al. Tumor necrosis factor-like weak inducer of apoptosis accelerates the progression of renal fibrosis in lupus nephritis by activating SMAD and p38 MAPK in TGF- $\beta 1$ signaling pathway. Mediators Inflamm. (2016) 2016:8986451. doi: $10.1155 / 2016 / 8986451$

87. Xia Y, Campbell SR, Broder A, Herlitz L, Abadi M, Wu P, et al. Inhibition of the TWEAK/Fn14 pathway attenuates renal disease in nephrotoxic serum nephritis. Clin Immunol. (2012) 145:108-21. doi: 10.1016/j.clim.2012.08.008

88. Zhao Z, Burkly LC, Campbell S, Schwartz N, Molano A, Choudhury A, et al. TWEAK/Fn14 interactions are instrumental in the pathogenesis of nephritis in the chronic graft-versus-host model of systemic lupus erythematosus. $J$ Immunol. (2007) 179:7949-58. doi: 10.4049/jimmunol.179.11.7949

89. Bertsias GK, Boumpas DT. Pathogenesis, diagnosis and management of neuropsychiatric SLE manifestations. Nat Rev Rheumatol. (2010) 6:358-67. doi: 10.1038/nrrheum.2010.62

90. Zhao X, Hao J, Duan H, Rong Z, Li F. Phosphoinositide 3-kinase/protein kinase $\mathrm{B} /$ periostin mediated platelet-derived growth factor-induced cell proliferation and extracellular matrix production in lupus nephritis. Exp Biol Med. (2017) 242:160-8. doi: 10.1177/1535370216668050

91. Rocha LP, Xavier SC, Helmo FR, Machado JR, Ramalho FS, Dos Reis MA, et al. Epithelial-mesenchymal transition in pediatric nephropathies. Pathol Res Pract. (2016) 212:1157-66. doi: 10.1016/j.prp.2016.09.008

92. Wang P, Yang J, Tong F, Duan Z, Liu X, Xia L, et al. Anti-doublestranded DNA IgG participates in renal fibrosis through suppressing the suppressor of cytokine signaling 1 signals. Front Immunol. (2017) 8:610. doi: 10.3389/fimmu.2017.00610

93. Liang Y, Xu WD, Peng H, Pan HF, Ye DQ. SOCS signaling in autoimmune diseases: Molecular mechanisms and therapeutic implications. Eur $J$ Immunol. (2014) 44:1265-75. doi: 10.1002/eji.201344369

94. Yung S, Zhang Q, Zhang CZ, Chan KW, Lui SL, Chan TM. Anti-DNA antibody induction of protein kinase $\mathrm{C}$ phosphorylation and fibronectin synthesis in human and murine lupus and the effect of mycophenolic acid. Arthritis Rheum. (2009) 60:2071-82. doi: 10.1002/art.24573

95. Zhang J, Tian XJ, Zhang H, Teng Y, Li R, Bai F, et al. TGF- $\beta$-induced epithelial-to-mesenchymal transition proceeds through stepwise activation of multiple feedback loops. Sci Signal. (2014) 7:ra91. doi: $10.1126 /$ scisignal.2005304

96. Yang C, Patel K, Harding P, Sorokin A, Glass WF, II. Regulation of TGF- $\beta 1 /$ MAPK-mediated PAI-1 gene expression by the actin cytoskeleton in human mesangial cells. Exp Cell Res. (2007) 313:1240-50. doi: 10.1016/j.yexcr.2007.01.011

97. Huang W, Xu C, Kahng KW, Noble NA, Border WA, Huang Y. Aldosterone and TGF- $\beta 1$ synergistically increase PAI-1 and decrease matrix degradation in rat renal mesangial and fibroblast cells. Am J Physiol Renal Physiol. (2008) 294:F1287-95. doi: 10.1152/ajprenal.00 017.2008

98. Zhang Y, Yang J, Jiang S, Fang C, Xiong L, Cheng H, et al. The lupus-derived anti-double-stranded DNA IgG contributes to myofibroblastlike phenotype in mesangial cells. J Clin Immunol. (2012) 32:1270-8. doi: 10.1007/s10875-012-9724-x

99. Furukawa F, Itoh T, Wakita H, Yagi H, Tokura $\mathrm{Y}$, Norris DA, et al. Keratinocytes from patients with lupus erythematosus show enhanced cytotoxicity to ultraviolet radiation and to antibodymediated cytotoxicity. Clin Exp Immunol. (1999) 118:164-70. doi: $10.1046 / j .1365-2249.1999 .01026 . x$

100. Boddu P, Nadiri M, Malik O. Diffuse bullous eruptions in an elderly woman: late-onset bullous systemic lupus erythematosus. Case Rep Dermatol. (2016) 8:278-82. doi: 10.1159/000448392

101. Doerner JL, Wen J, Xia YM, Paz KB, Schairer D, Wu L, et al. TWEAK/Fn14 signaling involvement in the pathogenesis of cutaneous disease in the MRL/lpr model of spontaneous lupus. J Invest Dermatol. (2015) 135:1986-95. doi: 10.1038/jid.2015.124

102. Xia Y, Herlitz LC, Gindea S, Wen J, Pawar RD, Misharin A, et al. Deficiency of fibroblast growth factor-inducible 14 (Fn14) preserves the filtration barrier and ameliorates lupus nephritis. J Am Soc Nephrol. (2015) 26:1053-70. doi: 10.1681/ASN.2014030233

103. Liu $\mathrm{Y}, \mathrm{Xu} \mathrm{M}$, Min $\mathrm{X}, \mathrm{Wu} \mathrm{K}$, Zhang $\mathrm{T}$, Li $\mathrm{K}$, et al. TWEAK/Fn14 activation participates in Ro52-mediated photosensitization in cutaneous lupus erythematosus. Front Immunol. (2017) 8:651. doi: 10.3389/fimmu.2017.00651

104. Hanly JG, Robichaud J, Fisk JD. Anti-NR2 glutamate receptor antibodies and cognitive function in systemic lupus erythematosus. J Rheumatol. (2006) 33:1553-8.

105. Chang EH, Volpe BT, Mackay M, Aranow C, Watson P, Kowal C, et al. Selective impairment of spatial cognition caused by autoantibodies to the N-methyl-D-aspartate receptor. EBioMedicine. (2015) 2:755-64. doi: 10.1016/j.ebiom.2015.05.027

106. Wen J, Xia YM, Stock A, Michaelson JS, Burkly LC, Gulinello M, et al. Neuropsychiatric disease in murine lupus is dependent on the TWEAK/Fn14 pathway. J Autoimmun. (2013) 43:44-54. doi: 10.1016/j.jaut.2013. 03.002

107. Janda A, Bowen A, Greenspan NS, Casadevall A. Ig constant region effects on variable region structure and function. Front Microbiol. (2016) 7:22. doi: $10.3389 /$ fmicb.2016.00022

108. Baudino L, da Silveira SA, Nakata M, Izui S. Molecular and cellular basis for pathogenicity of autoantibodies: lessons from murine monoclonal autoantibodies. Springer Semin Immunopathol. (2006) 28:175-84. doi: 10.1007/s00281-006-0037-0

109. Greenspan NS, Lu MA, Shipley JW, Ding X, Li Q, Sultana D, et al. IgG3 deficiency extends lifespan and attenuates progression of glomerulonephritis in MRL/lpr mice. Biol Direct. (2012) 7:3. doi: 10.1186/1745-6150-7-3 
110. Rekvig OP. The anti-DNA antibody: origin and impact, dogmas and controversies. Nat Rev Rheumatol. (2015) 11:530-40. doi: 10.1038/nrrheum.2015.69

111. Baudino L, Nimmerjahn F, Azeredo da Silveira S, Martinez-Soria E, Saito $\mathrm{T}$, Carroll $\mathrm{M}$, et al. Differential contribution of three activating IgG FC receptors (Fc $\gamma$ RI, Fc $\gamma$ RIII, and Fc $\gamma$ RIV) to IgG2a- and IgG2b-induced autoimmune hemolytic anemia in mice. J Immunol. (2008) 180:1948-53. doi: 10.4049/jimmunol.180.3.1948

112. Bardin N, Desplat-Jego S, Daniel L, Jourde Chiche N, Sanmarco M. BioPlex 2200 multiplexed system: simultaneous detection of antidsDNA and anti-chromatin antibodies in patients with systemic lupus erythematosus. Autoimmunity. (2009) 42:63-8. doi: 10.1080/089169308023 54906

113. Srdic-Rajic T, Jurisic V, Andrejevic S, Bonaci-Nikolic B, Bowker T, Concas $\mathrm{D}$, et al. Naturally occurring $\mathrm{V}$ region connected antibodies inhibit antidsDNA antibody reactivity with dsDNA. Immunobiology. (2012) 217:111-7. doi: 10.1016/j.imbio.2011.07.026

114. Xia Y, Janda A, Eryilmaz E, Casadevall A, Putterman C. The constant region affects antigen binding of antibodies to DNA by altering secondary structure. Mol Immunol. (2013) 56:28-37. doi: 10.1016/j.molimm.2013.04.004

115. Shuster AM, Gololobov GV, Kvashuk OA, Bogomolova AE, Smirnov IV, Gabibov AG. DNA hydrolyzing autoantibodies. Science. (1992) 256:665-7. doi: $10.1126 /$ science. 1585181

116. Cavallo MF, Kats AM, Chen R, Hartmann JX, Pavlovic M. A novel method for real-time, continuous, fluorescence-based analysis of anti-DNA abzyme activity in systemic lupus. Autoimmune Dis. (2012) 2012:814048. doi: $10.1155 / 2012 / 814048$

117. Ermakov EA, Smirnova LP, Parkhomenko TA, Dmitrenok PS, Krotenko NM, Fattakhov NS, et al. DNA-hydrolysing activity of IgG antibodies from the sera of patients with schizophrenia. Open Biol. (2015) 5:150064. doi: 10.1098/rsob.150064

118. Zeinab M, Hiam KM, Edmond C, Assem E. Selective adsorption of antiphospholipid and anti-dsDNA autoantibodies on histidine based pseudobioaffinity adsorbent from sera of patients with systemic lupus erythematosus (SLE). J Chromatogr B Analyt Technol Biomed Life Sci. (2015) 975:77-83. doi: 10.1016/j.jchromb.2014.11.005

119. Kostrikina IA, Buneva VN, Nevinsky GA. Systemic lupus erythematosus: molecular cloning of fourteen recombinant DNase monoclonal kappa light chains with different catalytic properties. Biochim Biophys Acta. (2014) 1840:1725-37. doi: 10.1016/j.bbagen.2014.01.027

120. Xia Y, Eryilmaz E, Zhang Q, Cowburn D, Putterman C. Anti-DNA antibody mediated catalysis is isotype dependent. Mol Immunol. (2016) 69:33-43. doi: 10.1016/j.molimm.2015.11.001

121. Kozyr AV, Kolesnikov AV, Khlyntseva AE, Bogun AG, Savchenko GA, Shemyakin IG, et al. Role of structure-based changes due to somatic mutation in highly homologous DNA-binding and DNA-hydrolyzing autoantibodies exemplified by A23P substitution in the $\mathrm{VH}$ domain. Autoimmune Dis. (2012) 2012:683829. doi: 10.1155/2012/683829

122. Touma Z, Gladman DD. Current and future therapies for SLE: obstacles and recommendations for the development of novel treatments. Lupus Sci Med. (2017) 4:e000239. doi: 10.1136/lupus-2017-000239

123. Arriens C, Wren JD, Munroe ME, Mohan C. Systemic lupus erythematosus biomarkers: the challenging quest. Rheumatology. (2017) 56(Suppl. 1):i3245. doi: 10.1093/rheumatology/kew407

124. Raker VK, Domogalla MP, Steinbrink K. Tolerogenic dendritic cells for regulatory $\mathrm{T}$ cell induction in man. Front Immunol. (2015) 6:569. doi: 10.3389/fimmu.2015.00569

125. Schulke S. Induction of interleukin-10 producing dendritic cells as a tool to suppress allergen-specific T helper 2 responses. Front Immunol. (2018) 9:455. doi: $10.3389 /$ fimmu.2018.00455

126. de Waal Malefyt R, Haanen J, Spits H, Roncarolo MG, te Velde A, Figdor C, et al. Interleukin 10 (IL-10) and viral IL-10 strongly reduce antigen-specific human $\mathrm{T}$ cell proliferation by diminishing the antigen-presenting capacity of monocytes via downregulation of class II major histocompatibility complex expression. J Exp Med. (1991) 174:915-24. doi: 10.1084/jem.174.4.915

127. Elizondo DM, Andargie TE, Haddock NL, da Silva RLL, de Moura TR, Lipscomb MW. IL-10 producing CD8(+) CD122(+) PD-1(+) regulatory
$\mathrm{T}$ cells are expanded by dendritic cells silenced for Allograft Inflammatory Factor-1. J Leukoc Biol. (2019) 105:123-30. doi: 10.1002/JLB.1A0118-010RR

128. Wong M, La Cava A, Hahn BH. Blockade of programmed death-1 in young (New Zealand Black x New Zealand White)F1 mice promotes the suppressive capacity of $\mathrm{CD} 4+$ regulatory $\mathrm{T}$ cells protecting from lupus-like disease. $J$ Immunol. (2013) 190:5402-10. doi: 10.4049/jimmunol.1202382

129. Francisco LM, Salinas VH, Brown KE, Vanguri VK, Freeman GJ, Kuchroo VK, et al. PD-L1 regulates the development, maintenance, and function of induced regulatory T cells. J Exp Med. (2009) 206:3015-29. doi: $10.1084 /$ jem.20090847

130. Obreque J, Vega F, Torres A, Cuitino L, Mackern-Oberti JP, Viviani $\mathrm{P}$, et al. Autologous tolerogenic dendritic cells derived from monocytes of systemic lupus erythematosus patients and healthy donors show a stable and immunosuppressive phenotype. Immunology. (2017) 152:648-59. doi: 10.1111/imm.12806

131. Xia Y, Zhang Y, Jiang S, Cheng H. CD4+ T-cell anergy induced by linCD117(c-kit) + stem cell-derived immature dendritic cells loaded with nuclear antigen derived from Trypanosoma equiperdum. Autoimmunity. (2010) 43:664-71. doi: 10.3109/08916931003674691

132. Xia Y, Jiang S, Weng S, Lv X, Cheng H, Fang C. Antigen-specific immature dendritic cell vaccine ameliorates anti-dsDNA antibody-induced renal damage in a mouse model. Rheumatology. (2011) 50:2187-96. doi: 10.1093/rheumatology/ker231

133. Sauer EL, Cloake NC, Greer JM. Taming the TCR: antigen-specific immunotherapeutic agents for autoimmune diseases. Int Rev Immunol. (2015) 34:460-85. doi: 10.3109/08830185.2015.1027822

134. Diamond B, Bloom O, Al Abed Y, Kowal C, Huerta PT, Volpe BT. Moving towards a cure: blocking pathogenic antibodies in systemic lupus erythematosus. J Intern Med. (2011) 269:36-44. doi: 10.1111/j.1365-2796.2010.02318.x

135. Gesheva V, Kerekov N, Nikolova K, Mihaylova N, Todorov T, Nikolova $\mathrm{M}$, et al. Suppression of dsDNA-specific B lymphocytes reduces disease symptoms in SCID model of mouse lupus. Autoimmunity. (2014) 47:162-72. doi: 10.3109/08916934.2014.883502

136. VanPatten S, Sun S, He M, Cheng KF, Altiti A, Papatheodorou A, et al. Amending HIV drugs: a novel small-molecule approach to target lupus anti-DNA antibodies. J Med Chem. (2016) 59:8859-67. doi: 10.1021/acs.jmedchem.6b00694

137. He M, Cheng KF, VanPatten S, Bloom O, Diamond B, Al-Abed Y. A structural investigation of FISLE-412, a peptidomimetic compound derived from saquinavir that targets lupus autoantibodies. Bioorg Med Chem Lett. (2017) 27:4725-9. doi: 10.1016/j.bmcl.2017.08.070

138. Zhang W, Reichlin M. A possible link between infection with burkholderia bacteria and systemic lupus erythematosus based on epitope mimicry. Clin Dev Immunol. (2008). 2008:683489. doi: 10.1155/2008/683489

139. Sthoeger Z, Sharabi A, Mozes E. Novel approaches to the development of targeted therapeutic agents for systemic lupus erythematosus. J Autoimmun. (2014) 54:60-71. doi: 10.1016/j.jaut.2014.06.002

140. Hahn BH, Singh RR, Wong WK, Tsao BP, Bulpitt K, Ebling FM. Treatment with a consensus peptide based on amino acid sequences in autoantibodies prevents $\mathrm{T}$ cell activation by autoantigens and delays disease onset in murine lupus. Arthritis Rheum. (2001) 44:432-41. doi: 10.1002/1529-0131(200102)44:2\&lt;432::AID-ANR62\&gt;3.0.CO;2-S

141. Yu Y, Liu Y, Shi FD, Zou H, Hahn BH, La Cava A. Tolerance induced by antiDNA Ig peptide in (NZBxNZW)F1 lupus mice impinges on the resistance of effector T cells to suppression by regulatory T cells. Clin Immunol. (2012) 142:291-5. doi: 10.1016/j.clim.2011.11.004

142. Ferrera F, Fenoglio D, Cutolo M, Balbi G, Parodi A, Battaglia F, et al. Early and repeated IgG1Fc-pCons chimera vaccinations (GX101) improve the outcome in SLE-prone mice. Clin Exp Med. (2015) 15:255-60. doi: 10.1007/s10238-014-0303-8

143. Sharabi A, Mozes E. The suppression of murine lupus by a tolerogenic peptide involves foxp3-expressing CD8 cells that are required for the optimal induction and function of foxp3-expressing CD4 cells. J Immunol. (2008) 181:3243-51. doi: 10.4049/jimmunol.181.5.3243

144. Parameswaran R, Ben David H, Sharabi A, Zinger H, Mozes E. B-cell activating factor (BAFF) plays a role in the mechanism of action of a 
tolerogenic peptide that ameliorates lupus. Clin Immunol. (2009) 131:22332. doi: 10.1016/j.clim.2008.12.009

145. Sthoeger ZM, Sharabi A, Molad Y, Asher I, Zinger H, Dayan M, et al. Treatment of lupus patients with a tolerogenic peptide, hCDR1 (Edratide): immunomodulation of gene expression. J Autoimmun. (2009) 33:77-82. doi: 10.1016/j.jaut.2009.03.009

146. Urowitz MB, Isenberg DA, Wallace DJ. Safety and efficacy of hCDR1 (Edratide) in patients with active systemic lupus erythematosus: results of phase II study. Lupus Sci Med. (2015) 2:e000104. doi: 10.1136/lupus-2015-000104
Conflict of Interest Statement: The authors declare that the research was conducted in the absence of any commercial or financial relationships that could be construed as a potential conflict of interest.

Copyright $(02019$ Wang and Xia. This is an open-access article distributed under the terms of the Creative Commons Attribution License (CC BY). The use, distribution or reproduction in other forums is permitted, provided the original author $(s)$ and the copyright owner(s) are credited and that the original publication in this journal is cited, in accordance with accepted academic practice. No use, distribution or reproduction is permitted which does not comply with these terms. 